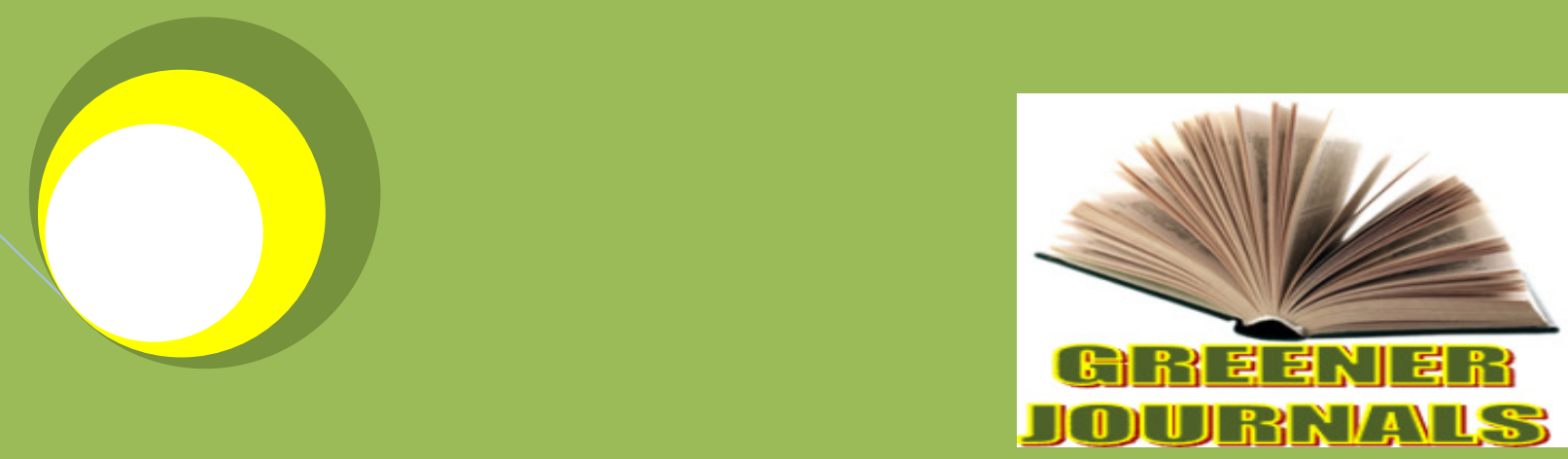

Greenerilournal ó Bususinessand Wanayement Sciencess ISSN: 2276-7827 Impact Factor 2012 (UJRI): 0.6670 ICV 2012: 6.03

Women in Commercialized Subsistence Economies: Profit and Factors Influencing Participation in Small- scale Cereal Processing and Marketing in Maiduguri, Borno state, Nigeria By

Bashir Alhaji Baba Dominic A. Anogie Yakaka Bukar Maina 


\title{
Women in Commercialized Subsistence Economies: Profit and Factors Influencing Participation in Small- scale Cereal Processing and Marketing in Maiduguri, Borno state, Nigeria
}

\author{
Bashir Alhaji Baba ${ }^{1}$, Dominic A. Anogie ${ }^{2}$ and Yakaka Bukar Maina ${ }^{3^{*}}$ \\ 1,2Lake Chad Research institute, Maiduguri, Borno State, Nigeria. \\ ${ }^{3}$ Department of Agricultural Economics, University of Maiduguri, Maiduguri, Borno State Nigeria.
}

*Corresponding Author's Email: bashir5880@gmail.com, Tel: 08025485009, 07032614009

\begin{abstract}
This study examined women in commercialized subsistence economies: profit and factors influencing participation in small-scale cereal processing and marketing in Maiduguri, Borno state, Nigeria. Specific objective include; examine socioeconomic characteristics of the women participating in processing and marketing of cereal; determine the factors influencing women participating in processing and marketing of cereal; examine the profitability of processing and marketing of cereal; identify women sources of initial investment in the business and identify constraints to processing and marketing of cereal in the study area. Cluster sampling technique was adopted, six (6) areas selected, and ten (10) women (processors and marketers) were randomly selected, marking sixty (60) women for the study. Findings of the study indicated that most of the women belong to the age bracket of 31 and above years (51.67\%), while $48.33 \%$ were between the ages of $18 \sim 30 \mathrm{yrs}$, The data on capital indicated $90 \%$ had an average initial investment 5,000 Naira and only $1.67 \%$ of the women participants invested an average of 65,000 Naira in the business. Revelation on profitability showed that $\mathbf{N} 2,287.72 \mathrm{k}$ as gross margin in the processing of cereal in the study area per $100 \mathrm{~kg}$ bag and that the highest cost incurred in the business was in the processing of the grains constituting $63.51 \%$ and the second highest cost incurred was cost of transportation (19.57\%). The regression estimates suggest number of measures (mudus) sold/day; household size and start up capital significant at $1 \%$. However, the negativity of the coefficients of age, marital status, household size, and education indicates that a $1 \%$ change in these variables will attract a reduction in the participation of women in the processing and marketing of cereal in the study area. The findings on problems indicated lack of credit facilities $(36.67 \%)$ as the most identified problem hindering their participation in processing and marketing cereal. Only $28.33 \%$ cited price fluctuation. The study recommends formation of group cooperative to enhance acquisition of loans for the business.
\end{abstract}

Keywords: Women, Commercialized. Subsistence, Cereal, Processing, Maiduguri.

\section{INTRODUCTION}

Policies fronting commercialization of processing agricultural produce such as cereal in Nigeria, increase incomes, and guarantee improved livelihood, food security, and subsequent reduction of poverty. Women are famous and major small-scale commercialised produce processors and prime economic actors, subsisting in local informal economies and prominently contributing to household work and welfare. Besides, rapidly growing and changing markets in the developing world provide real opportunities for women participation in the processing of agricultural produce, where many enhance the welfare of their families by adding value to rid excess glut. This also provides stimulation of output and consumption through market oriented traditions and augment employment opportunities (Obasi and Chukwuma, 2008; Opata and Nweze, 2009).

In most societies, gender inequities on resources and market tend to limit women's ability to engage in agricultural trade to complement economic gains (Jones et al., 2012; Mayoux et al., 2009; Van Zanden, 2004). Despite the constraints to produce high quality products due to lack of technology inputs, resources, and information among women processors and marketers, the demand for traditionally processed raw material continues to predominate in most developing countries (Gebremedhin et al., 2007). Regardless of women's poor economic background, lack of skills to cope with the competing pressures from their domestic responsibilities, time constraints, fewer marketable skills, and domestic child care responsibilities. Nevertheless, women strive to reign in commercialized subsistence small-scale economic spheres, mostly characterized by vicious cycle of low investment, productivity, and incomes; earning, and contributing to social wellbeing and food security. This study 
premised to examine women subsisting on small- scale cereal processing and marketing economy and factors influencing their participation, in Maiduguri, Borno State, Nigeria.

\section{Objectives of the Study}

The broad objective of this study is to examine Women in Commercialized Subsistence Economies: Profit and Factors Influencing Participation in Small- scale Cereal Processing and Marketing in Maiduguri, Borno state, Nigeria. The study sought to address the following specific objectives:

i examine the socioeconomic characteristics of the women participating in processing and marketing of cereal;

ii estimate the factors influencing women's participation in cereal processing and marketing;

iii examine the profitability in the business;

iv identify women sources of initial investment in the business and

$\mathrm{V} \quad$ identify constraints to processing and marketing of cereal.

\section{METHODOLOGY}

\section{Study Area}

The study area was Maiduguri Metropolis, the capital of Borno State, Nigeria. It lies within latitude $10^{\circ} 14^{\prime}$ North and longitude $11^{\circ} 30^{\prime} \mathrm{E}$ of the Greenwich meridian. It occupies a total land mass of $5,077 \mathrm{~km}^{2}$ with a population density of approximately 80 inhabitants per square kilometres. With growth rate of 3.4 percent per annum, the area was expected to hit a projected population of 1,059, 563 female by 2013; using 2006 National population figure (National Population Commission, 2006). Majority of the inhabitants are farmers, traders, and civil servants. The majority ethnic group is Kanuri, others include Shuwa Arabs, Babur/Bura, Marghi, Fulani and Hausa, and many immigrant settlers from within and outside Nigeria. Major crops produced in the area include millet, sorghum, maize, wheat and groundnuts. It is the tradition in the area processing cereal like millet into flour and course grit, for making akamu, Bulum kuluye, jingir, fura, Kunun tsamiya, burabusku and so on. Maize flour processed into masa, Tuwon masara, and course grit into biskin masara, and flour; and wheat into flour for making Dubla, Fungatsu, tarmutarmu and course grit into Ngaji laamaye, etc.

\section{Sampling Techniques}

Cluster sampling technique was adopted because, the population was localised in different locale in the study area; these areas were Custom market, Ngamboru market, Monday market, Bulumkuttu, Maduganari markets and Bulaburin area where most of Cereal were processed. In each of the areas, ten (10) women processors randomly selected, making sixty (60) respondents for the study.

\section{Analytical Techniques}

Descriptive statistics, Gross margin analysis and multiple regression models were used to achieved the stated specific objectives. The descriptive statistics include frequency distribution and percentages.

\section{Gross Margin Techniques}

Gross margin analysis forms the basis for assessing the profitability because the fix cost associated with processing was negligible.

WPGM $=$ WPGR - WPTVC

Where;

WPGM $=$ Women processors $/$ marketers gross margin $100 \mathrm{~kg} /$ bag of cereal processed and marketed WPGR $=$ Women processors $/$ marketers gross revenue $/ 100 \mathrm{~kg}$ bag of cereal processed and marketed WPTVC $=$ Women processors $/$ marketers total variable cost $/ 100 \mathrm{~kg}$ bag of cereal processed and marketed

\section{Multiple Regression model}

This technique was used to estimate the factors influencing women participation in processing cereal and marketing and was modelled as expressed: 
$\ln Y=a+\beta_{1} \ln X_{1}+\beta_{2} \ln X_{2}+\beta_{3} \ln X_{3}+\beta_{4} \ln X_{4}+\beta_{5} \ln X_{5}+\beta_{6} \ln X_{6}+\beta_{7} \ln X_{7}+U i$

Where;

$\mathrm{Y}=$ level of womenparticipation in processing of cereal (proxy to number of days involved in processing cereal)

$\mathrm{X}_{1}=$ Age $(\mathrm{yrs})$

$\mathrm{X}_{2}=$ Marital status

$\mathrm{X}_{3}=$ Household size (no of persons)

$\mathrm{X}_{4}=$ Husbands Education level (no yrs in formal settings)

$X_{5}=$ Number of Language spoken (no)

$\mathrm{X}_{6}=$ Husband's occupation

$\mathrm{X}_{7}$-start up capital

$\mathrm{X}_{8}=$ No of Measures sold

$\beta=$ regression coefficient

$\mathrm{e}=$ error term.

The linear, semi-log, exponential and double-log function were tried. Double-log function was selected as the lead equation based on the signs and significance of the coefficient, the magnitude of the coefficient of the determination $\mathrm{R}^{2}$ and the a priori expectation.

\section{RESULTS AND DISCUSSION}

\section{Socio-economic Characteristics of women Processors and marketers of cereal}

The socioeconomic characteristics of the women processors and marketers of cereal were examined and results were as presented in table 1.

Table1: Socio-economic Characteristics of Women Processor/Marketers of cereal

\begin{tabular}{lcc} 
Characteristics & Frequency & Percenta \\
\hline Age & & \\
$10-30$ & 29 & 48.33 \\
31 and above & 31 & 51.67 \\
Marital status & 22 & \\
Married & 18 & 36.7 \\
Single & 16 & 30.0 \\
Widow & 04 & 26.7 \\
Divorce & & 06.7 \\
Household size & 16 & \\
1.3 & 44 & 26.67 \\
4-6 & & 73.33 \\
Main occupation & 47 & 78.0 \\
Processing and Marketing & 03 & 5.00 \\
Farming & 02 & 03.3 \\
Civil Servant & 01 & 01.7 \\
Trader & 07 & 11.0 \\
Others & & \\
Level of Education & 11 & 18,3 \\
Primary & 15 & 25.0 \\
Secondary & 04 & 05,0 \\
Tertiary & 30 & 50.0 \\
Qur'anic & & \\
Working Capital & 54 & 9.0 \\
0-10,000 & 05 & 08.33 \\
10,001-20,000 & 00 & 0,00 \\
20,001-30,000 & 00 & 0.00 \\
30,001-40,000 & 01 & 01.6 \\
40,001-50,000 & & \\
& &
\end{tabular}




$\begin{array}{lll}\text { Current Capital } & & \\ 0-10,000 & 26 & 43.33 \\ 10,001-20,000 & 24 & 40.00 \\ 20,001-30,000 & 06 & 10.0 \\ 30,001-40,000 & 01 & 0.67 \\ 40,001-50,000 & 02 & 03.33 \\ 50,001-60,000 & 01 & 01.67 \\ \text { Working experience } & & \\ \text { 0-20yrs } & 53 & 88.33 \\ 21 \text {-above } & 07 & 11.67 \\ \text { Kind of Cereal } & & \\ \text { Processed/marketed } & & \\ \text { Sorghum } & 07 & 11.70 \\ \text { Maize } & 28 & 23.70 \\ \text { Rice } & 14 & 06.70 \\ \text { Wheat } & 04 & 0.70 \\ \text { Millet } & 07 & \end{array}$

Results from the study revealed that majority of the women processors had 31 and above years of age (51.67\%). This indicates that most of the women involved in processing cereal were in their active age; and are expected to be economically active and energetic. They should be willing to explore avenues and adopt new techniques in order to raise their level of productivity. Majority of the women were married (36.7\%), this indicates households willingness to diversify sources of income to supports household. The result also showed that majority of the women (73.33\%) had a household size of 4 and above. The study also showed that many $(50.0 \%)$ of the women had no formal education. In addition, majority had Qur'anic education (50\%). This is in line with findings of Goodland (2002) that most of the women involved in agricultural processing had not gone through formal system and majority were not educated beyond primary education. Results also show that $63.33 \%$ of the women could speak at least 3 languages. This indicates that most of the women could influence clients through effective communication to enhance the flow of customers. Most of the women (78.0\%) showed processing and marketing of cereal as their primary occupation, while only $11 \%$ had other jobs such as cleaning in other sectors of the society. The findings analyzed that $90 \%$ of the women had initial investment $0-10,000$ Naira in the business and only $1.67 \%$ of the women invested 40,001-50,000 Naira in the business. This agreed with the findings of Agu (1998); Adamu (1992) and CBN (2005) that most women who engaged in processing do not have enough capital to dedicate in agro-business.

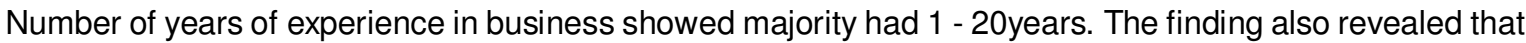
the most processed cereal in the study area was maize grain $(46.70 \%)$, trailed by rice $(23.30 \%)$ and sorghum and millet with $11.7 \%$ each. This indicated that maize was the most processed and command higher demand for processing among the women than rice, sorghum, and millet in the study area.

Table 2: Source of working capital for business

\begin{tabular}{lrc}
\hline Source of Capital & Frequency & Percentage \\
\hline Financial institution & 0.00 & 0.00 \\
Co-operative & 0.00 & 0.00 \\
Informal Lending & 31.0 & 51.70 \\
Husband/personal saving & 28.0 & 48.30 \\
\hline
\end{tabular}
Source: Field survey, 2012.

The analysis on working capital reveals that majority (51.70\%) of the women obtain their working capital through informal lending, while $48.30 \%$ of them from personal savings. This agreed with findings of Opata and Nweze (2009) that women processors and marketers of agricultural products have no access to loan from formal financial service (institution) due to lack of collateral, guarantor, and assets to stand as collateral. In the same vein, according to Aguilar and Veronica (2006) regarding limited-access to financial services, women depend largely on their own limited cash resources or, in some cases, loans from extended family members for investment capital. 


\section{Cost and Returns Analysis}

The costs incurred in the processing cereal by the women and total revenue computed and analyzed results were as presented in table 2 below.

Table 3: Cost and Returns in Cereal Processing/100kg bag/Processor

\begin{tabular}{|l|l|l|}
\hline Variable & Average Variable Cost & Percentage \\
\hline Purchasing price & 5,500 & \\
Revenue & $7,604.68$ & 10.60 \\
Cost of agrochemicals & 48.84 & 19.60 \\
Cost of transportation & 90.33 & 06.36 \\
Cost of loading/off & 29.33 & 63.44 \\
cost of processing & 292.32 & \\
\hline Total Average Cost & 460.82 & \\
GROSS MARGIN & $1,643.86$ & \\
\hline
\end{tabular}

Source: field survey, 2012.

The result revealed that on the average the women make total revenue of $\# 7,604.68 \mathrm{k} /$ per $100 \mathrm{~kg}$ bag processed, while the total variable cost was $460,82 \mathrm{k} / 100 \mathrm{~kg}$ bag. The analysis also revealed $\mathrm{N}$ I, $643.86 \mathrm{k}$ as Gross margin in the processing of cereal and marketing in the study area per $100 \mathrm{~kg}$ bag. This finding indicates that on the average a women processor earns $\mathrm{N} 1,643.86 / 100 \mathrm{~kg}$ bag as a profit. The analysis also showed that the highest cost incurred in the business was in the processing of the cereal, constituting $63.51 \%$ and the second highest cost incurred was cost of transportation (19.60\%); only $6.36 \%$ of the cost was accrued to loading and offloading. Costs of agrochemical constitutes the second least cost incurred and make up only $10.60 \%$; which could be attributable to the alternative biological means of pest control adopted by some of the women; using cats to scavenge on the rats during storage.

\section{Factors influencing Women Participation in Cereal Processing and marketing}

The results of the determinants of women participation in Cereal processing presented in table 4 . The result of the multiple regression estimate chosen based on econometric and statistical criteria showed the lead equation as the double log function. The estimated $R^{2}, 0.626$, implies that the model explained about $63 \%$ of the variation in participation of women in cereal processing.

Table 4: Regression Estimates of the Determinants Women Participation in processing cereal

Variable coefficient standard error t value

\begin{tabular}{lccl}
\hline & & & \\
Age & -0.021 & 0.019 & -0.221 \\
Marital status & -0.024 & 0.203 & -0.273 \\
Family size & -0.216 & 0.156 & $-2.431^{* * *}$ \\
Husbands education $(\mathrm{yrs})$ & -0.174 & 0.022 & $-1.817^{\star}$ \\
No Language spoken & 0.89 & 0.311 & 0.916 \\
Husbands Occupation & 0.118 & 0.146 & 1.318 \\
Start up capital & 0.543 & 0.000 & $5.166^{\star * \star}$ \\
No measure sold & 0.164 & 0.018 & $-1.687^{*}$ \\
$\mathrm{R}^{2}$ & 62.6 & & \\
Adj $\mathrm{R}^{2}$ & 57.6 & & \\
F-ratio & 10.667 & & \\
\hline
\end{tabular}

Source: field survey, 2012: ${ }^{* *}$ Significant at 1\%, ${ }^{*}$ Significant at $5 \%$, * Significant at 10\% ; NS=not significant

The findings suggest that household size, and start up capital as the most significant variables at $1 \%$. However, the negativity of the coefficients of age, marital status, household size, and husband's education indicates that a $1 \%$ reduction in these variables will increase the participation of women in the processing and marketing of cereal in the study area. The coefficient of education of the women' husband was negative and significant at $10 \%$. This implies that the higher the educational level of their husbands in the study area, the lesser may be the participation of women in the business. This also buttressed the coefficient of the husband's occupation which was positive, and this implies direct effect on the women's participation; suggesting the more educated the husband, the lesser will be likelihood of participation of their women in the business. The coefficient of language spoken is positive and 
indicates that the more proficient women are in the number of languages spoken, the more it would aid in negotiating price and customers attraction in the business.

The findings also revealed that start up capital had positive coefficient and was statistically significant at $1 \%$; judging from the data it was the most important variables among the ones considered in the study, indicating its profound effect on the participation of women in processing of cereal and marketing. This may be, the higher the start up capital, the more would be the likelihood of investing in the business, especially characterized by their small-scale operations most of the women seem to be caught in the vicious cycle of low investment, low productivity, and low incomes and are usually cash-strapped, and have limited access to credit for varied reasons. Thus, implication of small micro-finance credit service in increasing the productivity of women in the study area is likely to augment their level of participation in the business to generate income. This is in consonance with the findings of Freeman et al. (2004); Ellis and Bahiigwa (2003); Iheanacho (2001); Moser (1998) and Bzugu (1994); where women were analyzed in agro processing with results indicating access to well designed financial services can help poor women build assets and engage more in processing of cereal.

\section{Problem affecting Women participation in Processing Cereal and marketing}

Women involved in processing Cereal face a numbers of problems associated with business in the study area. Table 5 presents the problems face by women in processing in the study area.

Table 5: Distribution of Women based on the Problem of Processing and marketing of cereal

\begin{tabular}{lcc}
\hline Problem & Frequency & Percentage \\
\hline Credit facilities & 22 & 36.67 \\
Price fluctuation & 17 & 28.33 \\
Weather (Dust and wind) & 08 & 13.33 \\
Poor storage facilities & 07 & 11.67 \\
Pest & 06 & 10.00 \\
\hline
\end{tabular}

Source: Field survey, 2012.

The findings of the study suggest credit facility (36.67\%) as the most identified problem hindering their participation in processing of cereal. Considerably, this affects almost every participant to be up and doing the business. Second most pressing problem was price fluctuation representing $28.33 \%$ of the responses; suggesting, off season variation of cereal supplies' had tremendous effect on the cereal processing, when most of the supply have dwindled and price of cereal have risen. In addition, $23.33 \%$ of the women cited weather conditions, such as sand storm, dusty wind, rainfall, and moisture causing serious loss to women processors in the study area. Poor storage facilities problem constitutes $11.67 \%$ of the responses, and was the third most important problem associated with the business. Lack of modern storage facilities can limit deterioration of the processed cereal. The women cited Pest such as rats, cockroach, weevils as one of the problems in the storage of their cereal, constituting $10.00 \%$ of the responses. This was the least problem experienced by the women and could be attributable to the alternative biological means of pest control adopted by some of the women; using cats to scavenge on the rats during storage.

\section{CONCLUSION}

Start up capital was the most important influential factor in women's participation in small-scale cereal processing. Other important variables include household size and number of cereal (quantity) measures sold. Cereal processing was profitable; with lack of credit, and price instability as major constraints.

\section{RECOMMENDATION}

In the light of the above research conducted, the following policy recommendations are given:

1. The study recommends formation of women group or cooperative to enable active participation in the business.

2. Policy should be geared towards investment in such areas (processing industries). Microfinance institutions should be strengthened and should expand their support to resource poor women. 


\section{REFERENCES}

Adamu F (1992). "Hausa Purdah Women in Groundnuts Processing Enterprise". In Rural Development Strategies in Nigeria; Oiomala SA and Nwosu AC (eds) in Proceeding of the $6^{\text {th }}$ Annual Conference of the Nigerian Sociological Association. Pp.200-2001.

Agu CC (1998). Method of Enhancing Efficiency in Loan Processing, Evaluation and Disbursement; in MO ljere and A Korie (eds). Reading in Agricultural Finance .BENCOD Press Limited IGNMU Lagos. Pp. 2-20

Aguilar, Verónica González (2006). Women's Participation in Microfinance. http://www.globenet.org/horizon-local

Bzugu (1994). "Constrain to farm Resources Acquisition by Women Farmers in Semi-Arid zone" Paper Presented at $8^{\text {th }}$ Annual Conference of Nigerian Rural Sociology Association (NRSA) held at Ogun State University, Ago-Iwoye.

Central Bank of Nigeria (2005). Micro-finance Policy, Regulatory and Supervisory frame work for Central Bank of Nigeria, Abuja, Pp.6-11.

Ellis F, Bahiigwa G (2003). Livelihoods and rural poverty reduction in Uganda. World Development. 31 (6): 997-1013.

Freeman HA, Ellis F, Allison E (2004). Livelihoods and rural poverty reduction in Kenya. Development Policy Review. 22 (2): 147-171.

Gebremedhin B, Dirk H, Jemaneh S (2007). Heading towards commercialization? The case of live animal marketing in Ethiopia, International Livestock Research Institute (ILRI), Addis Ababa, Ethiopia.

Goodland A (2002). "Rural Finance Helping to Promote Sustainable Credit". UK: National Resources Institute (NRI). Electronic version: http/www.nri.org/publication/policy Series No. 1 pdf.

Iheanacho AA (2001). Economic and Educational Needs of Women in "Purdah" in Borno State of Nigeria. Journal of Education vol.3 No.2 pp 1-11.

Jones E, Smith S, Wills C (2012). Women producers and the benefits of collective forms of enterprise. Gender and Development. 20 (1): 13-32.

Mayoux L, Baluku P, Reemer T (2009). "Balanced Trees Grow Richer Beans: Community-led action learning for gender justice in Uganda coffee value chains." Paper presented to International Coffee Conference, Costa Rica, November 2009.

Moser CON (1998). The asset vulnerability framework: reassessing urban poverty reduction strategies. World Development. 26 (1) 1-19.

National population Commission (NPC) (2006). Nigeria's National Population Census.

Obasi IO, Njpkuoma EC (2008). Performance of rice market in Ebonyi State.Journal of economic theory. 2(1):22-23.

Opata PI, Nweze NJ (2009). Analysis of Informal Women's Cooperative Micro-finance Society in Lending to their Members for Processing and Marketing of Agri-products; proceeding of $23^{\text {rd }}$ Annual Conference of Farm Management Society of Nigeria, $14^{\text {th }}-17^{\text {th }}$ December, 2009. Department of Agricultural Economic, University of Nigeria Nsukka, Pp. 1 -6.

Van Zanden JL (2004). On the efficiency of markets for agricultural products. Rice prices and capital markets in 19th century Java." Journal of Economic History. 3 (3): 337-359. 